\title{
In Honor to Herman Lent's 90 Years and to his Major Contribuitions to the Memórias do Instituto Oswaldo Cruz
}

\section{Em Homenagem aos 90 Anos de Herman Lent e à sua Contribuição às Memórias do Instituto Oswaldo Cruz}

Herman Lent was born in Rio de Janeiro on 3rd February 1911, when the Instituto Oswaldo Cruz was already a national reference center in Medical and Biomedical Research.

Born the son of Polish immigrants, Lent lived in a historical old house at Praça Tiradentes, in the commercial and cultural center of Rio de Janeiro at that time. He completed his basic education at the traditional Colégio Militar (a military school), where famous public persons of distinction had studied. In 1928 he graduated as a land-surveyor (a technical professional course). As he had not been able to develop his aptitude for natural sciences in that military school, he decided to apply for the Medical School at the Universidade do Brasil - now the Universidade Federal do Rio de Janeiro, UFRJ. In
No início da segunda década do século passado, quando o Instituto Oswaldo Cruz já era uma referência nacional, Herman Lent nasceu no Rio de Janeiro, em 3 de fevereiro de 1911. Filho de imigrantes poloneses, residentes em um velho casarão da Praça Tiradentes, na época o "centrão" do Rio de Janeiro, Lent fez os seus estudos fundamentais no tradicional Colégio Militar desta cidade, berço de várias personalidades civis e militares, onde obteve, em 1928, o diploma de agrimensor (espécie de curso profissionalizante da época). Não havendo, naquele educandário, o curso de graduação em ciências naturais, sua primeira vocação, ingressou na Faculdade de Medicina da, então, Universidade do Brasil (hoje Universidade Federal do Rio de

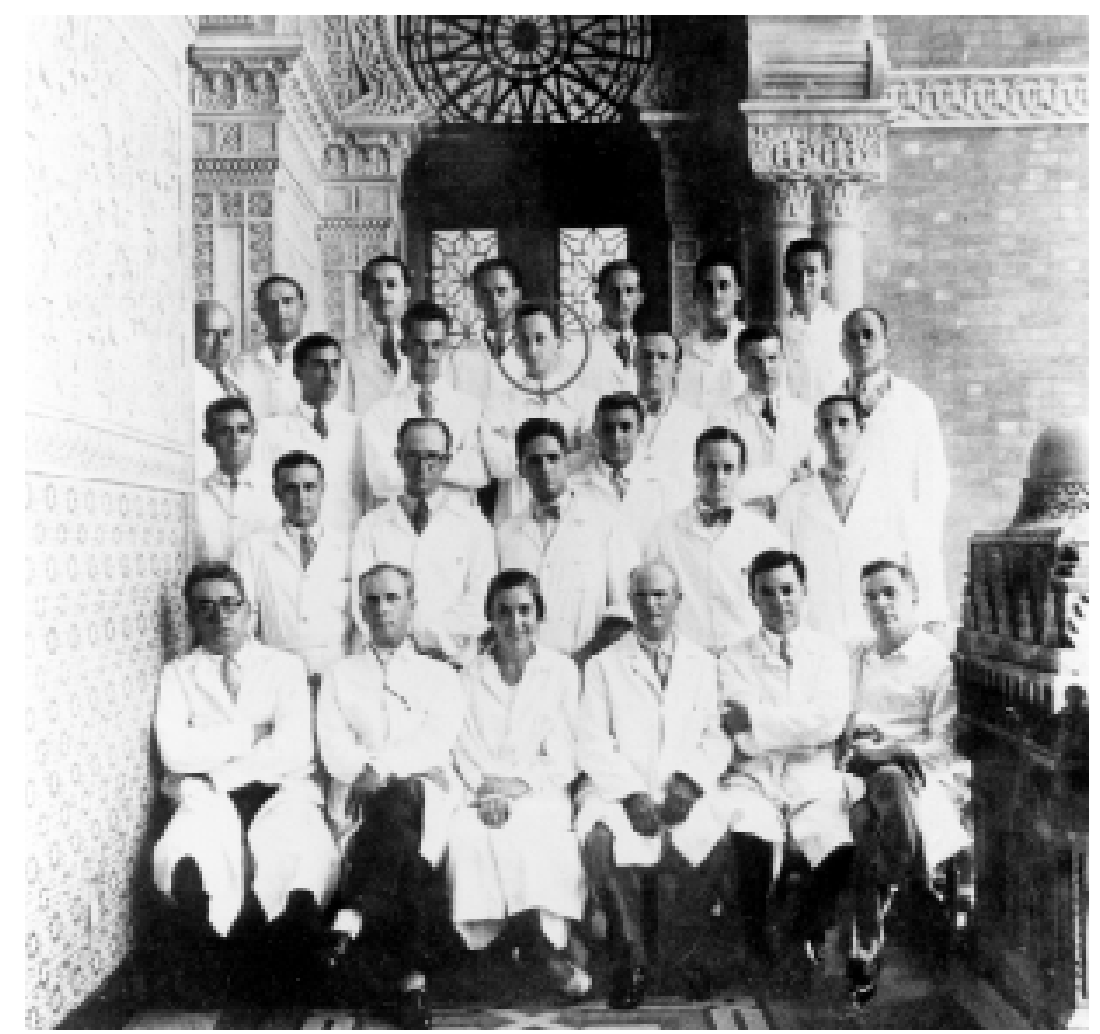

Herman Lent (circle) at the graduation of the Curso de Aplicação de Manguinhos in 1932 
this Medical School he met Pacheco Leão, the Professor of Parasitology, who noticed his interest in Biological Sciences and thus introduced him to Carlos Chagas - the Director of the Instituto Oswaldo Cruz at the time.

Lent, well-informed about the discovery of the Chagas disease in 1909 and the most recent studies on xenodiagnosis by Emille Brumpt, became interested in these scientific methods. Despite the fact that he was just 20 years old and still a student of Medicine, Chagas decided to invite him to apply for the Application Course of the Oswaldo Cruz Institute (Curso de Aplicação de Manguinhos), the very first post-graduation course in Brazil where thousands of scientists and Public Health professionals graduated in our country.

Lent attended the Curso de Aplicação from 1931 to 1932 as a third and fourth-grader medical student. During that time he got interested in Lauro Travassos' lectures - the greatest Brazilian helminthologist expert ever. He began to work as a trainee in Travassos' laboratory, where he met Teixeira de Freitas, his very partner and friend, with whom he published several papers.

As a sixth-grader medical student he published his first work "Sobre dois novos gêneros da subfamília Trichostrongylinae, Leiper, 1908, parasite of Tinamus solitarius Vieill", in the Memórias do Instituto Oswaldo Cruz, in June 1934. Out of the 232 papers already published, 75 (nearly one third of his scientific production) appeared in the Memórias. For many years he was a member of the Editorial Board and also the Editor of this journal in 1955 and in the 1959-1964 period.

After finishing the Curso de Aplicação de Manguinhos, Lent was appointed Biology Researcher and Professor of Helminthology in 1933 and later of Entomology in the Instituto Oswaldo Cruz. There he remained until April 1st, 1970, when he was compulsory retired together with nine of his colleagues by the military government, which deprived them of their political rights for ten years. He was later banned from teaching in any school maintained by the government. It was one of the most appalling demonstrations of power and injustice in that period. Lent himself dubbed this fact "O Massacre de Manguinhos".

In the afternoon of March 31st, 1970, when I went to his laboratory, located in the main building of Fundação Oswaldo Cruz - now used as a meeting room for the board of this institution, to invite him to teach Entomology in the newly-created Postgraduation Course on Infectious and Parasitic Diseases at the Universidade Federal do Rio de Janeiro, I was stopped by a security guard who said "Dr. Lent can't receive visitors". I told him I had an appointment with Dr. Lent and walked on.
Janeiro, UFRJ), onde o professor de parasitologia, Pacheco Leão, vendo o seu interesse pelas ciências biológicas, o apresentou a Carlos Chagas, na época diretor do Instituto Oswaldo Cruz. Lent, certamente inteirado sobre a descoberta da doença de Chagas, em 1909, e dos estudos iniciais de Emille Brumpt sobre o xenodiagnóstico, mostrou interesse por essa técnica, o que sensibilizou Chagas a convidá-lo um estudante de medicina, com apenas 20 anos de idade - para, excepcionalmente, realizar o Curso de Aplicação de Manguinhos, a primeira pós-graduação de fato, no Brasil, que formou centenas de cientistas e homens de saúde pública em nosso país.

Na qualidade de terceiro e quartanista de medicina, Lent cursou em 1931-1932 o Curso de Aplicação. Interessando-se pelas aulas de Lauro Travassos - o maior helmintologista brasileiro de todos os tempos - passou a estagiar em seu laboratório, onde encontrou Teixeira de Freitas, seu grande companheiro e amigo, com quem publicou numerosos trabalhos, sendo o primeiro "Sobre dois novos gêneros da sub-família Trichostrongylinae, Leiper, 1908, parasitos de Tinamus solitarius Vieill”, nas Memórias do Instituto Oswaldo Cruz, em junho de 1934, quando ainda estudante do $6^{\circ}$ ano da Faculdade de Medicina. Aliás, 75 dos seus trabalhos, quase um terço de sua produção científica (232 títulos que pudemos levantar), estão publicados nas Memórias da qual foi editor por dois períodos (1955e de 1959 a 1964) e membro do seu conselho editorial, durante alguns anos.

Logo após a conclusão do Curso de Aplicação, Lent foi nomeado, em 1933, pesquisador em biologia e professor de helmintologia do Instituto Oswaldo Cruz, onde permaneceu até $1^{\circ}$ de abril de 1970, quando foi aposentado, compulsoriamente, com nove de seus colegas, pelo Ato Institucional $n^{o} 5$ do Governo Militar, tendo os seus direitos políticos cassados por dez anos $e$, mais tarde, proibido de lecionar em qualquer estabelecimento de ensino do país, que recebesse financiamento do governo, no mais absurdo e injusto dos atos de força daquele período: o episódio retratado pelo próprio Lent como "O Massacre de Manguinhos".

Por coincidência, na tarde do dia 31 de março de 1970, fui ao seu laboratório, localizado no $1^{\circ}$ andar do Castelo, hoje sala de reuniões da presidência da Fundação Oswaldo Cruz, convidálo para dar o crédito de entomologia do recémcriado Curso de Pós-graduação em Doenças Infecciosas e Parasitárias da UFRJ. Ao subir a escada, fui obstado por um vigilante que me disse: “o Dr. Lent não está recebendo visitas". Disse- 
Dr. Lent and I did not know anything about his "compulsory retirement". We came to know about this fact on the newspapers next morning. We talked about my invitation and he decided to start the lessons in the post-graduation course in the second semester of that year but, unfortunately, that did not happen. I was delighted by the atmosphere of his laboratory, full of drawing boards, cameras lucidas, where he used to draw details of the innumerable species of triatomines he studied.

Professor Lent has fulfilled all the aspirations that a scientist, a professor or a researcher could dream of. In the beginning of his career at the Instituto Oswaldo Cruz he contributed enormously to the research in helminths studies, by describing several new species of helminth genus from different classes of animals, not only from Brazil but also from Argentina, Cuba and Venezuela. At the end of the thirties he started his entomological studies, publishing his first work with Arthur Neiva, Cesar Pinto and Felix Pifano (from Venezuela). In 1941 he published together with Arthur Neiva the "Sinopse dos Triatomineos". At this time he was working in both areas: Helminthology and Entomology. He finally decided for the latter when he was in charge of the Section of Entomology at the Instituto Oswaldo Cruz as of 1950 and devoted his time mainly to the studies of the triatomines, in which he is undoubtedly the most prominent specialist in the world.

His greatest work "Revision of the Triatominae (Hemiptera, Reduviidae) and their significance as vectors of Chagas disease", published in the Bulletin of the American Museum of Natural History (New York), 163 (3):125-520, figures 1-320, 1979, was written together with Peter Wygodzinsky, his former collaborator, and is a summary of his 40 years of studies on the triatomines up to that time. In order to write this book he was appointed Research Associate of that museum from 1975 to 1976.

While working at the Instituto Oswaldo Cruz as the Head of the Section of Entomology and as the Director of the Zoology Division he was also Professor at the renowned Colégio Pedro II and, also, in post-graduation courses in several universities in Brazil. He was Professor at the University of Asunción in Paraguay and at the University of Los Andes in Mérida, Venezuela.

He was Editor and member of the Editorial Board of several national and foreign journals, in special the Revista de Biologia, Academia Brasileira de Ciências, of which he was Editor for 40 years (19411981).

He was awarded several prizes and tributes, among which the Costa Lima Entomology Award of the Brazilian Academy of Science (1972) and in 1995 he received the National Order of the Scien-
Ihe que tinha um encontro marcado e fui entrando. Aparentemente Lent de nada sabia, como eu, sobre o ato de sua cassação, o que viríamos a saber na manhã seguinte pelos jornais. Conversamos e acertamos o crédito para o segundo semestre daquele ano, o que, logicamente, não aconteceu. Encantou-me o ambiente do seu laboratório, com várias pranchetas com aqueles braços de luz e câmaras claras, onde se desenhavam os inúmeros detalhes das várias espécies de triatomíneos que estudou.

Herman Lent foi, e é, tudo o que um cientista, pesquisador e professor poderia ter sido. No inicio de sua carreira no Instituto Oswaldo Cruz deu uma enorme contribuição ao estudo da helmintologia, descrevendo muitas espécies novas de diversos gêneros da fauna helmintológica, originárias de várias ordens de animais, não somente do Brasil, mas de outros países como Argentina, Cuba e Venezuela. No final da década de 30 iniciou suas incursões pela entomologia, publicando os primeiros trabalhos com Arthur Neiva, César Pinto e Felix Pífano (da Venezuela). Em 1941, publicou, com Arthur Neiva, a "Sinopse dos Triatomíneos", passando a dividir-se entre a helmintologia e a entomologia, assumindo definitivamente esta última especialidade quando passou a chefiar, no Instituto Oswaldo Cruz, a seção correspondente, a partir de 1950, dedicando-se especialmente aos triatomíneos, sobre os quais é, sem a menor dúvida, o maior especialista do mundo. Sua obra máxima, "Revision of the Triatominae (Hemiptera, Reduviidae) and their significance as vectors of Chagas disease", publicada no Bulletin of the American Museum of Natural History (New York) 163(3): 125-520, figs. 1-320, 1979, com Peter Wygodzinsky, seu antigo colaborador, resume sua experiência de 40 anos, na época, de estudos sobre os triatomíneos. Para realizar esse trabalho foi convidado por aquele тияеu, em 1975-1976, сото Research Associate.

Além de suas atividades no Instituto Oswaldo Cruz, como chefe da Seção de Entomologia e da Divisão de Zoologia, foi professor do Colégio Pedro II e de pós-graduação em diversas universidades do Brasil, na Universidade de Assunção, no Paraguai e na de Los Andes, em Mérida, Venezuela. Foi editor e membro do conselho editorial de várias revistas nacionais e estrangeiras, destacando-se a Revista de Biologia, da Academia Brasileira de Ciências, da qual foi editor durante 40 anos (1941-1981). Recebeu vários prêmios e distinções, entre os quais o Prêmio Costa Lima de Entomologia da Academia Brasileira de Ciências (1972) e a Ordem Nacional do Mérito Científico no grau de comendador (1995) e tantos outros constantes de seu currículo, de 
tific Merit commendation and many other prizes mentioned in his curriculum and in a notable biography - Homenagem da Revista Brasileira de Zoologia, 10:1-17,1993 - written by his disciple José Jurberg. These facts are also mentioned in three publications: in the Isto É magazine (24 July, 2000 ) by the journalist Viviane Rosalem, in the Sunday Supplement of Jornal do Brasil (4 June, 2000) by Daniel Tabak, and in the on-line magazine Ciência Hoje (August, 2001).

In conclusion to these brief words about Herman Lent, I would like to highlight two points of his personality and character. In 1976, Brazil was still under the military regime when he returned from the United States. He was then welcomed by Madre Maria de Maron Ramos, chancellor of the Universidade Santa Úrsula, who invited him to teach in that institution as a full professor. Later on, in 1985, the "compulsory retired" professionals of the Instituto Oswaldo Cruz were re-integrated. He was the only one who did not accept to go back to work at the institute, out of his gratefulness to Madre Maria de Maron for having helped him in those difficult times.

Professor Lent is not that kind of easy-going person. When he comes to defending his ideas, he can be very intransigent, ironic and tough even towards his friends. On the other hand, he is a kind-natured man, as shown in one of his last works with José Jurberg and Rodolfo Carcavallo, entitled "Panstrongylus sherlocki sp. n. do Estado da Bahia (Hemiptera, Reduviidae, Triatominae)" in which he honored a researcher whom he had severely criticized for classification mistakes in an article published in the Memórias do Instituto Oswaldo Cruz, in 1982.

In honor to Herman Lent's 90 years, we are publishing this editorial in Portuguese and in English despite the fact that, when asked to send us his curriculum, he wrote a note: Please, don't worry about me. At the age of 90 (and a half), I've done enough although I don't want to leave now. We hope he will not do it soon, and he will never leave our memory. sua rica biografia publicada por seu discípulo José Jurberg - Homenagem da Revista Brasileira de Zoologia 10: 1-17, 1993 e de reportagens dos jornalistas Viviane Rosalem (Revista Isto É, de 24 de julho de 2000) e Daniel Tabak (Revista de Domingo do Jornal do Brasil, de 4 de junho de 2000), e da Ciência Hoje on-line, de agosto de 2001.

Nestas breves palavras sobre Herman Lent gostaria de destacar alguns pontos de sua personalidade e de seu caráter. Por ter sido acolhido por Madre Maria de Maron Ramos, chanceler da Universidade Santa Úrsula, como professor titular daquela universidade, quando do seu regresso dos Estados Unidos em 1976, em plena ditadura militar, foi o único dos cassados a não aceitar a reintegração ao Instituto Oswaldo Cruz, em 1985, por reconhecimento e por gratidão a Madre Maria que o recebera naquele difícil momento. Lent não é de temperamento dócil; defensor intransigente de suas convicções, às vezes é irônico e muito duro, inclusive com seus amigos, na defesa de sua verdade; outras vezes é de uma doçura comovente, como em um de seus últimos trabalhos, que assina com José Jurberg e Rodolfo Carcavallo, intitulado "Panstrongylus sherlocki sp. n. do Estado da Bahia (Hemiptera, Reduviidae, Triatominae)" em homenagem a um pesquisador a quem fez duras críticas, por um erro de classificação em um trabalho publicado na Memórias do Instituto Oswaldo Cruz, em 1982.

Em homenagem aos 90 anos de Herman Lent, estamos publicando este editorial em inglês e em português, apesar do seu pedido no bilhete onde encaminhava o currículo solicitado: "Por favor, não se preocupe comigo. Aos 90 anos (e meio) já fiz o bastante, embora não deseje encerrar o expediente". Deus queira que não o encerre tão cedo; pelo menos jamais o fará em nossa memória.

\section{José Rodrigues Coura}

Editor
Portrait of Herman Lent made during the celebration of the Centenary of Oswaldo Cruz Institute (25 May 2000). 